\title{
Performance Poetry as a Performative Act: A Close Listening to Andrea Gibson's Poetry
}

\author{
Sahar Elmougy*
}

\section{Performance Poetry and Cultural production}

In the year 1917, Amy Lowell deplored the entrapment of poetry on the printed page. "Poetry is as much an art to be heard as is music, if only we could get people to understand the fact. To read it off the printed pages without pronouncing it is to get only a portion of its beauty, and yet it is just this that most people do" (Lowell 1917, 46). Lowell was drawing attention to the acoustic quality of poetry as an essential layer of signification. It is no exaggeration to say that in the past century, performance poetry has come to exceed Lowell's ambition. Performance poetry has chartered a new path for poetry, parallel to the printed page, albeit embedding the aesthetics of performance. The poem's meaning broke free from the confines of the printed page to include the poetperformer's physical presence, his/her interaction with a live audience as well as the paralinguistic and paratextual elements of the performance mode. The genre of performance poetry has come to be regarded as "one of the most significant developments in English-language poetry" (Novak 2011, 30).

Julia Novak (2011) places performance poetry as a subgenre under the broader umbrella of live poetry (33) which includes the traditional poetry readings (62). She states that:

live poetry can be defined as emerging from the fundamental bimediality of the genre of poetry - i.e. its potential realisation as spoken or written word - as a specific manifestation of poetry's oral mode of realisation, which is a parallel to, rather than a mere derivative 'version' of, the written mode. As such, live poetry is characterised by the direct encounter and physical co-presence of the poet with a live audience. The poet will predominantly perform his/her own poetry and is thus cast in the double role of "poetperformer.' The story and images of the poem are conveyed through

\footnotetext{
* Lecturer in the Department of English Language and Literature, Faculty of Arts, Cairo University.

Cairo Studies in English - 2020(2): https://cse.journals.ekb.eg/
} 
the spoken word rather than through theatrical ostension, as focus is placed on the oral verbalisation of the poetic text. (62)

In defining performance poetry, it is important to differentiate it from spoken word although some critics and poets use the two terms interchangeably. Both subgenres belong to the same oral mode of realization. But while spoken word is "a broader concept which may include prose, poetry, or even storytelling or stand-up comedy", performance poetry is strictly poetry put in the performance mode (33).

The genealogy of performance poetry throws light on one of its most significant characteristics, namely, its position against the mainstream. In its inception during the Harlem Renaissance, its growth over the twentieth century and its booming in the last four decades, performance poetry has always engaged in social, political and poetic opposition to the mainstream. In his theorizing for performance poetry, Jonah Raskin (2011) discusses the impact of Allen Ginsberg's performance of "Howl" in 6 Gallery in San Francisco which sent political and poetical shock waves across the US. Raskin (2011) states that"after a year of writing and rewriting, "Howl" evolved into a poem about coming out: sexually, politically, and poetically. It became a poem about the act of writing and the act of performing poetry (30). Eventually, "the cultural wave that the Beats and the Beatniks had started morphed into the counterculture" of the 1960s (30). Since then, performance poetry has maintained its counterculture position. In the UK and the US, it could be encountered in a wide variety of settings from poetry slams and open mic events to anti-war gatherings, literature festivals and "formal settings" such as universities, to name but a few (Novak 2011, 62).

This counterculture position is discussed in the introduction to Performing Poetry: Body, Place and Rhythm in Poetry Performance. Cornelia Grabner and Arturo Casas (2011) highlight "the positioning of performed poetry on the intersection between the social, the political, and the poetic" (17):

The poetry performance explores the implications of this hybridity and develops the creative possibilities that it opens up, especially for those who find themselves in marginal positions or who experience their identity as multiple. Moreover, the contingency of form and content allows for the conclusion that the performance of poetry as a practice and "performance poetry" as a genre highlight the significance of the cultural for the social and the political, and that it 
provides artists with a powerful mode of critiquing and challenging mainstream cultures. (18)

Along the same lines, De La Rosa (2013) discusses the ability of spoken word and slam poetry to be "a powerful form of cultural production":

Similar to its artistic and political roots found in the Harlem Renaissance, the Black arts movement, jazz, the beatniks, Hip Hop, and so forth, spoken word and slam poetry are also the outcomes of diverse genealogies that have come to highlight social, political, and spiritual realities, experiences, and cultures of marginalized bodies and identities. As such, spoken word poetry is an example of how performance is a powerful form of cultural production that allows for the creation and expression of alternative and multiple knowledges. (1)

The "alternative and multiple knowledges" offered by the genres of slam poetry, spoken word and performance poetry is evident in the variety of voices expressive of marginalized identities such as the African Americans, LGBTQ and poets with left-wing political views. The poetry and live performances of performance poets give voice to the multiple groups who are not at home in mainstream culture. In The Cultural Politics of Slam Poetry (2009), SomersWillet states that "Poets' proclamations of marginalized identities on the slam stage are articulations of diversity performed in resistance to the (somewhat exaggerated) homogeneity of official verse culture" (69). Performance poetry, just like its subgenre sisters slam poetry and spoken word, registers various articulations of marginalized identities.

\section{Performance Studies and Performativity}

The field of performance studies and theories of performativity offer insights into the various ways performance poetry operates on the level of cultural production. Performance studies highlights how the term "performance" has escaped the confines of the classical definition of an act imitating life, or what is real. Performance poetry represents an example of this perception of "performance" because when a poet performs his/her poem, the audience does not perceive this "performance" as an act. The poem speaks of the identity of the poet, his/her self is laid bare for the audience to witness and share in the creation of this identity. Performance studies deal with this collapse of boundaries 
between what is an act and what is real. In Performance Studies: An Introduction (2013), RichardSchechner highlights this collapse of boundaries between what is an act and what is real. He states how "[p]erformances have come to be seen as "any action that is framed, enacted, presented, highlighted, or displayed" (2). Schechner elaborates:

Performance must be construed as a "broad spectrum" or "continuum" of human actions ranging from ritual, play, sports, popular entertainments, the performing arts (theatre, dance, music), and everyday life performances to the enactment of social, professional, gender, race, and class roles, and on to healing (from shamanism to surgery), the media, and the internet. (2)

In such light, more people are experiencing their daily lives as a chain of performances, often overlapping:

dressing up for a party, interviewing for a job, experimenting with sexual orientations and gender roles, playing a life role such as mother or son, or a professional role such as doctor or teacher. The sense that "performance is everywhere" is heightened by an increasingly mediatized environment where people communicate by fax, phone, and the internet, where an unlimited quantity of information and entertainment comes through the air. (Schechner 2013, 49)

Performativity is even a broader term pointing to an array of possibilities offered by a world where clear demarcations between what is an "act" and what is "real", media and live events, and performing onstage or in everyday life are collapsing, and "[i]ncreasingly, social, political, economic, personal, and artistic realities take on the qualities of performance" (123). In the field of performance studies, the term "performativity" "points to a variety of topics, among them the construction of social reality including gender and race, the restored behavior quality of performances, and the complex relationship of performance practice to performance theory" (123).

First conceived by linguistic philosopher J. L. Austin in How to Do Things with Words (1962), the term "performative" was coined to describe utterances which are also actions such as promises, bets, curses and contracts. These 
utterances do not describe actions; they are actions (Austin 1962, 8-10). Austin (1962) states:

The term [...] "performative" is derived, of course, from "perform" $[\ldots]$ : it indicates that the issuing of the utterance is the performing of an action. [...] The uttering of the words is, indeed, usually a, or even the, leading incident in the performance of the act. (6-8)

But while Austin made a differentiation between the performative utterances which are actions and the same utterances turned hollow when said by an actor onstage or in a poem, performativity developed in an opposite direction since Austin. It has become an approach that perceives social reality as a construct (Schechner 2013, 123). It was Postmodernism which stretched the "performance principle" so that it would apply to all aspects of social as well as artistic life (129). Hence, nowadays, "[p]erformance is no longer confined to the stage, to the arts, and to ritual" (129).

It is important to realize that Postmodernism, as "a practice in the visual arts, architecture, and performance art" and Poststructuralism as "an academic response to postmodernism" constitute practices and theories of performativity (123), and that these practices and theories are in essence anti-authoritarian and subversive:

The first wave of scholars and artists - those who devised poststructuralism and practiced postmodernism - were vehemently anti-authoritarian. They elaborated Austin's ideas of performativity in ways that were philosophically, politically, and aesthetically antiauthoritarian. Today's poststructuralists and postmodernists continue this work of subverting the established order of things. (Schechner 2013, 141)

Judith Butler is one of the poststructuralist theorists who developed Austin's performatives. Sharing with the poststructuralists the broad objective of "decentering", their "attack on every kind of hegemony, authority, and fixed system - philosophical, sexual, political, artistic, economic, artistic" (Schechner 2013, 147), Butler theorized for gender as a performative act. Her basic premise is that "[g] ender reality is performative, which means, quite simply, that it is real only to the extent that it is performed" (Butler 1988, 527). She also points out that if the ground of gender identity "is the stylized repetition of acts through 
time, and not a seemingly seamless identity", then the possibilities of gender transformation lie in a different sort of repeating, a breaking or subverting of this style (520). Uncovering the hegemonic processes which create inscribed gender performatives, comparing gender roles to rehearsed theatrical performances, Butler is sharing in the poststructuralist endeavor to undermine "inscribed" power as Derrida names it. For him, "writing" is more than graphic inscription and literature; writing is extended to include cultural expressions and social practices which create entire systems on "inscribed" power: laws, rituals, traditions, hierarchies, politics, economic relations, science, the military, and the arts (Schechner 2013, 143). Derrida (1998) highlights the inextricability of writing and power (50). The fact that writing enacts agendas of power, i.e. those who write are actually performing authority, should not make us overlook the fact that writing and power never work separately. Derrida (1998) states:

Fostering the belief that writing fosters power [...] that it can ally itself to power, can prolong it by complementing it, or can serve it, the question suggests that writing can come [arriver] to power or power to writing. It excludes in advance the identification of writing as power or the recognition of power from the onset of writing. It auxiliarizes and hence aims to conceal the fact that writing and power never work separately, however complex the laws, the system, or the links of their collusion may be. (50)

The Derridean identification of writing as power, "the fact that writing and power never work separately", illuminates the politics of performance poetry and how it is constantly engaging with and challenging inscribed power. It is as if the poets are using the holes and open cracks in the collective narrative to rewrite counter-hegemonic narratives representing marginalized voices and communities. But these counter-narratives do more than represent the marginalized. The act of writing/performing becomes an act of creating identities and communities.

\section{For the Sake of Close Listening}

A decade ago, scholars and critics were faced with a general lack of critical tools suited to the study of poetry in the performance mode. Novak (2011) points out how literary criticism continued to "sideline or outright ignore live poetry as a subject for academic study" while providing an array of analytical tools "geared towards extracting the potential, 'imagined' sound that is 'built into the 
written poem' but no critical tools with which to attend to the spoken word...." (55). She states that:

[t]aking aspects such as body language or audience interaction into account would therefore require a paradigmatic shift in poetry criticism from a system of thought that privileges the written mode as it purports to provide methods for an analysis of poetry's sensual acoustic aspects, to an approach that fully acknowledges live performance as an alternative realisation mode and thus directs the critic's attention to a range of novel criteria that have hitherto been dismissed as lying outside the domain of literary criticism. (55)

In Live Poetry, Novak realizes this "paradigmatic shift in poetry criticism". Rather than dealing mainly with the verbal content of poetry and the potential sound of poems, she provides the scholar of live poetry with a toolkit capable of dealing with the poem as an acoustic and a theater event.

The live poetry toolkit allows for a close listening to the performed poem where an examination of the paralinguistic and paratextual features is integral to the meaning and effect of performed poetry. On the one hand, the live poetry toolkit looks into the paralanguage which is "the non-verbal voice qualities, modifiers and independent sounds and silences with which we support or contradict the simultaneous or alternating linguistic and kinetic structures" (Poyatos quoted in Novak 2011, 76). The toolkit examines layers of signification offered by aspects of vocal behavior such as the voice qualities, speed, loudness, pitch, the use of hesitation and intonation (Novak 2011, 76). On the other hand, it looks into the effect of the paratextual features such as the poet's physique, dress code and body communication.

\section{Gender is not a Fact}

Over the last two decades, Andrea Gibson had four published collections of poetry and seven CDs. Believing in and acting upon the motto of Vox Feminista (a multi-media performance group of radical feminists), "comfort the disturbed and disturb the comfortable" (Gibson 2015), Gibson tours extensively and performs their poems in as many venues as they can. The mediatic and cultural hybridity of the genre of performance poetry is realized in Gibson's performances which engage with elements of theater, performance art and music. And when onstage, it is clear that Gibson is not putting on an act. The poet presents their true identity. Gibson's body and dress code speak of their 
defiance of the gender binary of male/female just like their choice of the pronoun "they".

Gibson is fully aware of walking a path where activism and writing/performing go hand in hand (Gibson January 11, 2018). They state that:

several years ago I started noticing that my priorities as a writer were changing. I recognized that I wanted to make art that helped; art that had the potential to change something for the better. That was my number one hope going into every show, and while it's the nature of spoken word to write on themes of social justice, I hadn't always been that clear in my reasons for doing what I do. (Gibson January $11,2018)$

Much of what Gibson writes is about gender and gender queerness. They give voice to those who defy gender binaries. But the curious thing is that they do not write what they know. Gibson writes in order to know (Gibson April 8, 2019). Hence, writing does not perform the task of self-explanation as much as it becomes a process of self-exploration (Gibson January 29, 2018). In multiple interviews, they use many verbs to reflect on one act, that of knowing. Gibson states for instance that they write to "unpack", "learn about", "discover", and "uncover" their gender (Gibson May 1, 2018). Unearthing is another verb Gibson uses when they state that "often I am a different person after finishing a poem, because of the parts of myself I unearth in the process" (Gibson January 29, 2018).

The idea of creating one's gender, reiterated quite often by Gibson, resonates strongly with Judith Butler's theoretical formulation of gender as a performative, a cultural construct entrenched in the social. For Butler (1988), gender reality is a performance, i.e. it is real only to the extent that it is performed (527). She states that gender identity is a performative accomplishment compelled by social sanction and taboo (520). Butler (1988) elaborates:

The act that one does, the act that one performs, is, in a sense, an act that has been going on before one arrived on the scene. Hence, gender is an act which has been rehearsed, much as a script survives the particular actors who make use of it, but which requires individual actors in order to be actualized and reproduced as reality once again. (526) 
At the heart of the performativity of gender is the body. When Butler states that one "does" one's gender, she is simultaneously saying that "one does one's body" (521). The body is the stage where the performative plays itself out. Butler recalls Simone De Bouvoire's statement on the body, and how it "is a manner of doing, dramatizing, and reproducing a historical situation" (italics in original, Butler 1988, 521). She takes Bouvoire's statement as a springboard towards an affirmation that "the body is not just matter but a continual and incessant materializing of possibilities" (italics in original, 521).

In performance poetry, the meaning of a poem stretches to encompass, in addition to the verbal language, the poet's body language. Gibson's poems, many of which deal with gender queerness, acquire signification from the themes as well as from the way Gibson's body challenges rather than reproduces the dominant gender binary. This segment of the essay focuses on "Boomerang Valentine" because the poem does not deal with gender issues. In the absence of gender politics, the weight of the analysis will not fall on the theme but rather on the way Gibson's body and dress code represent an act of gender queerness.

Performing "Boomerang Valentine" (Gibson December 28, 2018), Gibson is wearing a hat which covers their short hair but not the relatively longer hair on the forehead. They are wearing a plain unisex grey vest. The grey T Shirt under the vest shows the contours of their arms which are well-toned but not exactly masculine. The tattoos on both arms, between the wrists and elbows appear like bracelets, but they are not exactly feminine. In brief, Gibson's body is hard to classify according to the classical gender binary. They state: "I don't necessarily identify within a gender binary. I've never in my life really felt like a woman and I've certainly never felt like a man. I look at gender on a spectrum and I feel somewhere on that spectrum that's not landing on either side of that" (Gibson 2015). In "Boomerang Valentine", Gibson's gender queer physique becomes a paratext to the performed poem.

In "Boomerang Valentine", Gibson seems to be expanding on the first two lines of "Your Life", another poem which deals with the queer position outside the gender binary. In the opening lines of "Your Life", the poet states: "It isn't that you don't like boys/ It's just that you only like boys you want to be" (Gibson 2017) . "Boomerang Valentine" goes on to explore the question of self-love albeit painted in gender queer language. In the opening lines, the audience knows about the poet being "intentionally single and celibate for the first time since I was 20 years old" (Gibson December 28, 2018). Back then, they believed "sex had to involve a dude and the word "screw" (Gibson December 28, 2018). The two words I put in bold letters are the first in the poem to receive stress and a 
stretching of the two long vowels in "dude" and "screw". The stresses seem to underline a fallacy entertained earlier in the poet's life. Gibson is telling their friend about the psychic who said they will meet the love of their life by the end of January. But it is January 10th and they are "far from ready for Cupid, that naked little shit, to fire anything sharp my way" (Gibson December 28, 2018). When the friend poses the question: "What if you are the love of your life?" (Gibson December 28, 2018), Gibson stretches their arms forward with open palms as if welcoming the invitation. The gesture is accentuated by another stress on "you" and an elongated "u" sound. This is followed by an exclamatory tone where Gibson shakes off the idea "because I am absolutely not my type" (Gibson December 28, 2018). Negation is also represented in a hands' gesture. However, Gibson decides to consider for a moment what if they are actually their type: "Let's say I am my dream girlish boyish girl" (Gibson December 28, 2018). The description of that potential self-as-lover depicts a gender identity that breaks away from the male/female binary replacing it with the non-binary of "girlish boyish girl". The description is accompanied by a hand gesture that juggles the adjectives from one hand to the other and then back.

Music, soft and subtle, comes in with the line starting with "Let's say", and stays in the background as Gibson explores the possibility of this romance. In comparison to the opening lines of the poem, the tempo slows down as the scene is drawn of Gibson standing at their front step, ringing the bell, waiting for themselves to answer "so I can hand myself a mason jar full of water lilies I have rescued from a millionaire's Monet" (Gibson December 28, 2018). The poem moves from the depiction of the first meeting where Gibson is charmed by the self-as-lover to an assumption that they are not just chewing on an "old cliche" which says we have got to love ourselves:

we don't

I know I can keep getting down on myself 'til I'm tucked into the grave

Looking up at my name, carved in stone, wondering why I never knew I'd been cast the lead in my own life. (Gibson December 28, 2018)

As shown in the above lines, the idea of self-love leads to an exploration of the reasons behind its absence; namely, self-beating, and undervaluing the self.

In the next segment, Gibson ushers the audience into the dilemma by using the pronoun "you" and a finger pointing towards the attendees. The hypothesis 
is expanded not just when it comes to each one being cast the lead in their lives, but also to how we are violent towards ourselves, framing what we perceive as flaws, forgetful of things like "tenderness" and "compassion" (Gibson December $28,2018)$. However, a turning point takes place as Gibson continues:

No

that is not how anything grows

Of all the violence I have known in my life, I have not known violence like the way I have spoken to myself. (Gibson December $28,2018)$

The "no" is delivered in staccato. Disconnected from what comes before it, the negation stands on its own, a stressed beat located in the middle between two short pauses. Another stress falls on "grows". The assonance of the "o" vowel creates an exclamatory tone related to the reminder that nothing could grow from that place of violence. A faster tempo takes the audience through a depiction of self-loathing, as if the legato utterance (where words are smoothly connected) is an enactment of the self-beating:

And I have seen almost everyone around me hold that same belt to their own backs

An ambush of every way we have decided we are not enough

Then, looking for someone outside of themselves to come clean that treason up. (Gibson December 28, 2018)

Posing the question: "If I were to ask myself out of that cycle" (Gibson December 28, 2018), Gibson is playing on the double meaning of "ask out". The verb breaks from the confines of the dating game and comes to refer to breaking out of dominant cultural cliches which fuel self- loathing. In order to break free from that cycle, Gibson states the kind of self-talk necessary for the process. They repeat "I am still" in four consecutive sentences. They are still going through their "growth spurt"; they are still "yet to get my worst tattoo"; they are still "clearing the smoke from burning the toast I wrote for my own wedding day"; and they are still "trying to get rid of my mirror face/ Look myself dead in the eye" (Gibson December 28, 2018). The repetition of "I am still" is delivered in a fast and rhythmic tempo that seems to come from a gush of life experienced by the poet. This strong tempo materializes the future state of becoming and its endless possibilities. Admitting they have not survived certain things, knowing 
other people had to work to survive them, Gibson moves towards a final affirmation that:

\author{
I want the heavy to anchor me brave \\ to anchor me loving \\ to anchor me in something that will absolutely hold me to my word \\ When I tell Cupid I intend to keep walking out to the tip of his arrow \\ To bend it back towards myself \\ To aim for my goodness; 'til the muscle in my chest tears from the \\ stretch of becoming \\ When I came here to be a lover of whatever got covered up by the \\ airbrush \\ The truth of me: that beauty of a beast. (Gibson December 28, 2018)
}

Judith Butler (1988) argues against gender being a fact since "the various acts of gender create the idea of gender, and without those acts, there would be no gender at all" (521). The way out of the scripted performativity of gender lies in its very character as a performative. That is to say, when "individual actors choose not to actualize and reproduce the gender performative there is a possibility of contesting gender's "reified status" (520). Discussing the complex links and the difficulty of drawing the line between theatrical and social roles, Butler pinpoints how "gender performances in non-theatrical contexts are governed by [...] punitive and regulatory social conventions" (527). Her argument refers to forms of theater which contend with and even break down the conventions that demarcate the imaginary from the real. In such cases, "the act is not contrasted with the real, but constitutes a reality that is in some sense new, a modality of gender that cannot readily be assimilated into the pre-existing categories that regulate gender reality" (527). In performance poetry, poetperformers are not perceived as performing an imaginary act. They represent their identities. Gibson is one of the "individual actors" who chooses not to walk the trodden path of the gender performative.

\title{
Performance of Authorship
}

In 1988, Peter Middleton presented the concept of "performance of authorship" which applies to authors reading their works whether or not they are conscious of their performance. In his essay "The Contemporary Poetry Reading" (1988), Middleton focuses on authors demonstrating their authority by reading aloud. He discusses the significance of the physical presence of the 
speaker "to a specific body, point of view, and history. Such effects are obviously greatly amplified when the speaker is the author, when the moment of reading acts as a figure of an imaginary moment of composition" (268). According to Middleton, both the words spoken and the speaker earn credibility and authority through live performance. In her Ph.D. dissertation "The Role of the Poet: Poetry Performance at the Beginning of the Twenty First Century" (2010), Mary Elizabeth Jones-Dilworth adds another layer of meaning to the performance of authorship. She defines "authority" as "not only as the authorness of the poet, but the ability to influence" (9).

While Middleton and Jones-Dilworth discuss the performance of authorship as a means of realizing authority, Somers-Willet stretches the concept to make it apply to the way authors gain authenticity. In The Cultural Politics of Slam Poetry: Race, Identity and the Performance of Popular Verse in America (2009), Somers-Willet explores how the slams act as "cultural stages where poets perform identities and their audiences confirm or deny them as 'authentic' via scoring" (8). Authenticity is achieved when the audience feels a performance to be honest, sincere and reflective of lived experience. In performance poetry, there is no scoring like in the politics of slam poetry. Yet the poet is still granted or denied authenticity through the reception of the audience. Gibson's performance poetry realizes the multiple dimensions of authorship. Middleton's definition of "the performance of authorship" applies to Gibson's work, mainly characterized by the quality of liveness. Despite being a published author, Gibson views live performances as a major constituent of her poetic identity. Gibson states:

I think that especially with spoken word [...] it has an energy behind it that's very emotional. And I think it requires a lot of emotional presence by the person speaking the poem [...] it's a conversation between the poet and the audience and the audience in a lot of ways sort of pulls the emotion and pulls the poem out of the poem and I think that when we're creating art from an emotional place it's really effective because I don't think people typically respond and change things in their lives from facts. If you're on stage and you start talking about the statistics of the number of deaths in Iraq, the numbers just reaches people's heads. You're gonna be more effective if you get up and honestly and emotionally tell the story of one Iraqi mother. (Gibson December 27, 2018) 
The connection Somers-Willet (2009) establishes between performance of authorship and authenticity also applies to Gibson's work. It is evident to their audience that the poetry speaks of the identity of the poet. The words are in sync with the poet's authentic self. But gender is not the only constituent of Gibson's performance of authorship. In many of their poems, they speak openly about their depression and panic attacks. Gibson performs those poems with the awareness that the space of performance poetry is a space for uncovering who they really are (Gibson April 15, 2019). This act of uncovering influences the audience. It comforts the disturbed (Gibson 2015). It assures them they are not alone. Others suffer states of intense emotions, but they speak about them. And the act of speaking out transforms these feelings. They metamorphose into empowerment.

Gibson's "Ode to the Public Panic Attack" (Gibson January 15, 2018) is one example of this act of uncovering which is simultaneously a performance of authorship. The poem, as evident from the title, is about the poet's panic attacks. In both their interviews and poetry, Gibson speaks openly about suffering panic attacks and depression. They also criticize the cultural conditioning when it comes to expressing emotions. They state:

just being expressive with your feelings and the ways that we're culturally expected to closet our emotions. The idea that there's just a closet around love or sexuality is sort of hilarious. I think we're also that way with grief and panic and anxiety and depression, and I think we also closet our bliss. We're culturally expected to taper it all down. (Gibson 2015)

Gibson admits to having full-blown panic attacks onstage. Whenever this happens, they perform "Ode to the Public Panic Attack" in an act of radical honesty and vulnerability (Gibson August 2, 2018). The poem depicts the overwhelming emotional nature of panic attacks, and in its last segment, Gibson subverts the perception of panic attacks as weakness. The poet begins by directly including the audience members as both the addressees of the poem and witnesses to her confession of suffering panic attacks. The first four sentences begin with "You find me" (Gibson January 15, 2018). Gibson is found "at the movies/ at the coffee shop, at the grocery store buying comfort food", they are found "on dates", at "Disney world/ in line for the Little Mermaid/Slow moving Clam ride" and at "parties so often I stopped celebrating my own birthday" (Gibson January 15, 2018). The tempo in the opening lines of the poem is slow 
in comparison to what will follow. With each of the four sentences/scenes the tempo accelerates, and the legato utterances create a sense of fluidity as if the scenes coexist. The tempo gets even faster till it becomes breathless as the audience sees Gibson on the airplane:

You found me on the airplane, then in the arms of the medic, after the plane stopped on the runway and turned around to let me off.

Don't worry, the medic said, It's just a panic attack. (Gibson January 15, 2018)

Being on an airplane is immediately followed by "then in the arms of the medic" with no breath before "then" as if being on the plane is one and the same thing as being in the arms of the medic. This sentence is uttered in one breath and in a very fast tempo which reenacts the breathlessness of the panic attack. It is as if being on an airplane entails the collapse of chronological time characteristic of states of panic, hence the overlapping of the panic attack, the plane stopping to let them off and the "don't worry" of the medic.

The first time a word receives stress, becomes a beat, is found in the next sentence where Gibson stresses the "that" in the answer to the medics' sentence. They take a short breath before: "as if that would comfort me" (Gibson January 15, 2018). Explaining what is meant by "that", the following two lines also embed stressed beats. In the following lines, the words in bold are uttered in staccato; the are disconnected from the rest of the utterance:

as if that would comfort me,

to be told I am the enemy,

my body its own stalker. (Gibson January 15, 2018)

The tempo slows and the stresses fall on the "I", "am" and "enemy". The staccato highlights the struggle of the self-suffering the panic attack, its being both the victim and the enemy. Gibson translates this idea in the following image:

That's just my heart

giving my sternum a high five

fifty times a second. (Gibson January 15, 2018). 
A "high five" is a casual greeting gesture that does not entail intense emotions. However, Gibson accompanies the stresses on the number of heartbeats a second with a slapping motion of her right hand, a slap with each beat of the three: "fifty", "times" and a "second". The strong and fast slaps create a paratext for the emotional turbulence accompanying the attack, a layer of signification that is not present in the verbal content. Another instance of significant body movement takes place with the following lines:

Just relax and calm down

always seems like helpful things to scream

if oxygen has never been over your head,

if your body has never become its own corset. (Gibson January 15, 2018)

With the last image, Gibson hugs her torso tightly with both arms. Her voice as a result chokes with the tightness of the body becoming "its own corset" and the less oxygen coming into their lungs. Their voice is stifled, its volume down.

In a middle segment of the poem, Gibson states how they would have liked to make their audience "uncomfortable" with their politics but not with their "body flailing like the about-to-be-dead-girl in a teenage horror flick" (Gibson January 15, 2018). Gibson makes her (comfortable) audience uncomfortable through her politics of gender. But could they also be creating this state of discomfort through the performance of their own vulnerability, the laying bare of states of panic attacks while the poet-performer is on stage giving their poem? There is a certain paradox here, a liminal space hosting both vulnerability and the performative of speaking it out. But the performative in this case is subversive. It does not perpetuate the act of closeting emotions. The final lines of the poem point in this direction.

Unlike the fluid and legato-like nature of the previous lines, indicative of the overwhelming nature of panic attacks, the final segment witnesses a slower tempo and a louder volume which takes a crescendo curve. Gibson's voice is louder with more staccato utterances evident in the stresses falling on the "I", the "am" and the "done" in "I am done with the shame/ the cage of self hate". The slower tempo of this utterance, its loudness and staccato-like nature not just accompany the turn of meaning, they perform the act of subversion. Through an affirmative tone of voice and a tall strong body, Gibson delivers an utterance which transforms the shame and self-hate into a celebration of their courage. There is courage in "knowing there is a promised jaw" outside their door and 
still stepping "towards the horror" (Gibson January 15, 2018). There is also courage in the act of laying bare one's vulnerability in front of the gazing eyes of the audience/witnesses. On this affirmative tone, Gibson wraps up the poem:

\author{
I am done with the shame, the cage of self hate \\ the lie that this is weakness when I am certain it is \\ the mightiest proof of my strength. \\ how hard it is to live knowing there is a promised jaw \\ outside my front door \\ and still I step towards the horror \\ still I say here I am world \\ let's make relaxation look like a crime we'll never get busted for. \\ Let's hyperventilate \\ Like it is 1999. (Gibson January 15, 2018)
}

Grabner and Arturo Casas (2011) point out how the performance of poetry obliges poets to address the question of authorship (11). One of the possibilities opened up by this question is that "the performance can frame individual authorship within a context of community or collectivity" (11). In this light, Gibson's poems on depression and panic attacks could be seen as an attempt to use authorship to create a community for those who suffer not just similar states of emotional vulnerability but also the social expectations of closeting their emotions. "Ode to the Public Panic Attack" ends with an invitation which involves the audience, hence completing the circle of audience involvement. While the early lines of the poem address the audience as witnesses to the confession of suffering panic attacks, the last lines extend an invitation to the audience as a collectivity capable of taking action. The poet urges the audience: "let's make relaxation look like a crime..." (Gibson January 15, 2018). Gibson states that her therapist's definition of depression is to push down, or depress feelings; then they point out how writing, which is an act of expression, is the very opposite of depression (Gibson April 8, 2019). "Ode to the Public Panic Attack" is but one of many examples where Gibson heals the emotions that have been depressed through the act of writing and the public act of performing. This double act of writing/performing is a subversive performative.

\title{
Etching defiant narratives
}

Acting upon the belief that no writing is first or final, that no narrative is closed, performance poetry offers rich possibilities for re-writing cultures. It is 
an open arena for performative acts which challenge and decenter social constructions such as that of gender. In discussing two of Gibson's poems where gender is not the thematic focus, this essay was allowing space for a close listening to the messages delivered through the paralinguistic and the paratextual features. Whether gender is the focus or not, Gibson's live presence onstage and their body language communicate an alternative knowledge. In the space of performance poetry, Gibson is not only creating their identity, but they are also performing authorship in a way that offers validation for the emotionally vulnerable and for other gender queers. Gibson provides their audience with what they missed while growing up shrouded in shame and fear (Gibson January $22,2018)$, namely courage and acceptance of one's identity. This space for validation is an indication of cultural change. Butler's assumption that in the very character of gender as a performative lies the possibility of deconstructing it, is fully realized in the performance poetry of Gibson who belongs to a much bigger mosaic of performance poets etching defiant narratives. Gibson is well aware that the act of speaking the truth is a political act, so is the act of creating art and putting beauty in the world (Gibson December 10,2018). They never fail to act upon this belief.

\section{Works Cited}

Austin, J. L. 1962. How To Do Things With Words. London: Oxford UP.

Butler, Judith. 1988. "Performative Acts and Gender Constitution: An Essay in Phenomenology and Feminist Theory." Theater Journal 40, no. 4 (December): 519-531. <https://www.jstor.org/stable/3207893?read-now=1\&seq=1\#page_ scan_tab_contents>.

De La Rosa, Erica Granados. 2013. "Up next: The Epistemic Power of Spoken Word Poetry." PhD diss., U of Texas. Retrieved from The U of Texas at Austin Digital Repository.

$<$ twu-ir.tdl.org/bitstream/handle/11274/3590/2013GranadosDeLaRosaOCR. pdf? sequence $=6 \&$ isAllowed $=\mathrm{y}>$.

Derrida, Jacque. 1998. The Derrida Reader: Writing Performances. Lincoln: U of Nebraska P.

Gibson, Andrea. 2019. "Interview with spoken word poet Andrea Gibson ahead of their show at the NAC." Interview by Ing Shannon. Apt 613, April 15, 2019. Accessed July 7, 2019. <apt613.ca/andrea-gibson-interview/>. 
-----. 2019. "Conversations with Poets We Love: Andrea Gibson.” Interview by Ugwu Uzoma. Medium, April 8, 2019. Accessed July 7, 2019. $<$ medium.com/a-tired-heroine/conversations-with-poets-we-loveb2db3007cbbb>.

-----. 2018. "Boomerang Valentine." Button Poetry, December 28, 2018. Accessed January 15, 2019.

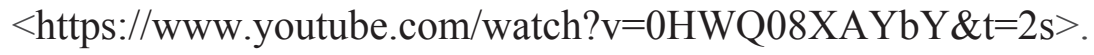

-----. 2018. "Andrea Gibson's "Lord of the Butterflies" Celebrates Constant Transformation." Interview by Elizabeth Hoover. Bitch Media, December 27, 2018.Accessed 7 December 2019. <www.bitchmedia.org/article/andreagibson-lord-butterflies-interview>.

----. 2018. “'I Write Where I want to be': Spoken Word Poet Andrea Gibson.” Interview by Audrey Nowakowski. WUWM, December 10, 2018.Accessed 1 July 2019. <www.wuwm.com/post/i-write-where-i-want-be-spoken-wordpoet-andrea-gibson\#stream/0>.

----. 2018. "Ode to the Public Panic Attack." Button Poetry, October 25, 2018. Accessed January 15, 2019. <https://www.youtube.com/watch? $\mathrm{v}=\mathrm{Nje} 28 \mathrm{djr}$ 9DM\&list=PLouSItjZ4srsTP0_DUsoCylFDwyCAYbRk\&index $=27 \& \mathrm{t}=13 \mathrm{~s}>$. -----. 2018. "Can You Write Love Poems in the Trump Era: A Q \& A with Genderqueer Artist Andrea Gibson." Interview by Sadie Dingfelder. The Washington Post, August 2, 2018. Accessed March 5, 2019. $<$ www.washingtonpost.com/express/wp/2018/08/02/can-you-write-lovepoems-in-the-trump-era-a-qa-with-genderqueer-artist-andrea-gibson/>. -----. 2018. "Poet Andrea Gibson Shares How They Learned About Their Gender Identity Through Writing." Interview by Kylie Groat. Seventeen, May 1, 2018. Accessed March 15, 2019. <www.seventeen.com/life/a20102112/andreagibson-interview-on-poetry/>.

-----. 2018. "Genderqueer Artist Andrea Gibson Uses Words to Send an Important Message: 'You Belong'." Interview by Corrina Allen. Brit, January 29, 2018. Accessed January 3, 2019. <www.brit.co/genderqueer-poet-andreagibson-uses-words-to-send-an-important-message-you-belong/> .

----. 2018. “Artist Interview: Poet Andrea Gibson On New York." Interview by DoNYC.DoNYC, January 22, 2018. Accessed July 10, 2019. $<$ donyc.com/p/interview-poet-andrea-gibson-talks-nyc-dog-parks-more $>$.

. 2018. "This Queer Slam Poet Fires Back at Gender Norms." Interview by Skylar Kergil. Them, January 11, 2018. Accessed March 5, 2019. $<$ www.them.us/story/andrea-gibson-hey-galaxy>. 
-----. 2017. "Your Life". YouTube, September 29, 2017. Accessed February 11, 2018. <https://www.youtube.com/watch?v=gsUp6Wd_o8I >.

-----. 2015. "The Pioneering Poet." Interview by Tig Notaro. Interview Magazine, April 22, 2015. Accessed 15 January 2019. $<$ www.interviewmagazine.com/culture/andrea-gibson>.

-----. 2011. "Speak Truth: CM Interviews Andrea Gibson." Interview by Diana Kraikittikun. College Magazine, September 16, 2011. Accessed 15 January 2018. <www.collegemagazine.com/college-magazine-interviews-andreagibson/>.

Grabner, Cornelia and Arturo Casas, eds. 2011. Performing Poetry: Body, Place and Rhythm in the Poetry Performance. New York: Rodopi, Amsterdam. ProQuest Ebook Central, <ebookcentral.proquest.com/lib/pitt-ebooks/detail. action?docID $=3008292>$.

Jones-Dilworth, M. Elizabeth. 2010. "The role of the poet: Performance poetry at the beginning of the twenty-first century." $\mathrm{PhD}$ diss., U of Texas. Retrieved from The U of Texas at Austin Digital Repository: <hdl.handle.net/2152/ETDUT-2010-05-1060>.

Lowell, Amy. 1917. "Poetry as a Spoken Art”. The Dial, January 25, 1917.

Middleton, Peter. 1998. "The Contemporary Poetry Reading." Close Listening: Poetry and the Performed Word, edited by Charles Bernstein, 262-299. New York: Oxford UP.

Novak, Julia. 2011. Live Poetry: An Integrated Approach to Poetry In Performance.Amsterdam: Editions Rodopi. ProQuest Ebook Central: $<$ ebookcentral.proquest.com/lib/aucegypt/detail.action?docID=819916>.

Raskin, Jonah. 2011. "Allen Ginsberg, 'Howl', and the 6 Gallery Poetry Performance." In Performing Poetry: Body, Place and Rhythm in the Poetry Performance, edited by Cornelia Grabner and Arturu Casas. Amsterdam: Rodopi. ProQuest Ebook Central: <ebookcentral.proquest.com/lib/pittebooks/detail.action?docID $=3008292>$.

Schechner, Richard. 2013. Performance Studies: An Introduction. New York: Routledge.

Somers-Willett, Susan B. A. 2009. The Cultural Politics of Slam Poetry: Race, Identity, and the Performance of Popular Verse in America. Ann Arbor: U of Michigan P. 